EGU2020-20272

https://doi.org/10.5194/egusphere-egu2020-20272

EGU General Assembly 2020

(c) Author(s) 2021. This work is distributed under

the Creative Commons Attribution 4.0 License.

\title{
Sr isotopes indicate millennial-scale formation of metal-rich layers by reactive melt percolation in an open-system layered intrusion
}

\author{
J. Stephen Daly ${ }^{1}$, Luke Hepworth ${ }^{2}$, Brian O'Driscoll ${ }^{3}$, Chris Johnson ${ }^{3}$, Ralf Gertisser², and C. Henry \\ Emeleus $^{4}$ \\ ${ }^{1}$ University College Dublin, UCD School of Earth Sciences, Science Centre West, Dublin, Ireland (stephen.daly@ucd.ie) \\ ${ }^{2}$ Keele University, School of Geography, Geology and the Environment, Keele, United Kingdom \\ ${ }^{3}$ University of Manchester, School of Earth and Environmental Sciences, Manchester, United KIngdom \\ ${ }^{4}$ Durham University, Durham, United Kingdom
}

In order to test whether the crystal mushes that form layered mafic intrusions can behave as open systems, we investigated mineral-scale textural, chemical and Sr isotopic heterogeneity in the c. 60 Ma Rum intrusion, Scotland. Within Unit 10 of the Rum intrusion, intercumulus plagioclase and clinopyroxene crystals in peridotite $1-2 \mathrm{~cm}$ above and below millimetric $\mathrm{Cr}$-spinel seams exhibit complex optical and chemical zoning (Hepworth et al. 2017). These $\mathrm{Cr}$-spinel seams are closely associated with sulphide and platinum-group element (PGE) mineralization. High precision Sr isotopic analyses (undertaken by thermal ionisation mass spectrometry) of individual intracrystal zones (sampled by micromilling) in intercumulus plagioclase and clinopyroxene from within the PGE-enriched $\mathrm{Cr}$-spinel seams have revealed significant intra-crystalline heterogeneity. ${ }^{87} \mathrm{Sr} /{ }^{86} \mathrm{Sr}$ heterogeneity is present between plagioclase crystals, between clinopyroxene and plagioclase, and within plagioclase crystals, throughout the studied section. The preservation of $\mathrm{Sr}$ isotope heterogeneities at 10-100 $\mu \mathrm{m}$ length-scales implies cooling of the melts that formed the precious metal-rich layers at rates $>1{ }^{\circ} \mathrm{C}$ per year, and cooling to diffusive closure within $10 \mathrm{~s}-100 \mathrm{~s}$ of years. The combined textural observations and intra-crystal plagioclase ${ }^{87} \mathrm{Sr} /{ }^{86} \mathrm{Sr}$ data also highlight the importance of repeated cycles of dissolution and recrystallization within the crystal mush, and together with recent documentation of 'out-of-sequence' layers in other layered intrusions (Mungall et al. 2016; Wall et al. 2018), raise the prospect that basaltic magmatic systems may undergo repeated self-intrusion during solidification.

Hepworth, L.N., O'Driscoll, B., Gertisser, R., Daly, J.S. and Emeleus, H.C. 2017. Journal of Petrology 58, 137-166; Mungall, J. E., Kamo, S. L. \& McQuade, S. 2016. Nature Communications 7, 13385; Wall, C. J., Scoates, J. S., Weis, D., Friedman, R. M., Amini, M. \& Meurer, W. P. 2018. Journal of Petrology 59, 153-190. 